\title{
KECANGGIHAN TEKNOLOGI INFORMASI, PARTISIPASI MANAJEMEN, PENGETAHUAN MANAJER AKUNTANSI DALAM EFEKTIVITAS SISTEM INFORMASI AKUNTANSI PT INDAH YATAMA AIR CARGO JATENG
}

\author{
Suprihati, LMS. Kristiyanti \\ Institut Teknologi Bisnis AAS Indonesia \\ Email: suprihati4566@gmail.com
}

Abstract

This type of research used in this research is quantitative methods. This study uses primary data obtained through questionnaires. Respondents in this study were users of accounting information systems at PT Indah Yatama Air Cargo in Surakarta and Semarang, as many as 36 respondents. The sampling technique used was saturated sampling or census. The data analysis method in this study used multiple linear regression analysis. The results showed that the variable of information technology sophistication had a positive and significant effect on the effectiveness of the accounting information system, while the management participation and knowledge management variables had no significant effect on the effectiveness of the accounting information system. Meanwhile, simultaneously the results of this study indicate that the variables of technological sophistication, management participation, and knowledge of accounting managers have a significant effect on the effectiveness of accounting information systems. The coefficient of determination shows a value of 54,0\%, the remaining $46,0 \%$ is explained by other variables outside of this study.

Keywords: information technology sophistication, management participation, knowledge of accounting managers, effectiveness of accounting information systems.

DOI: http://dx.doi.org/10.29040/jap.v22i1.2498

\section{PENDAHULUAN}

Peningkatan penggunaan teknologi komputer merupakan imbas dari perkembangan teknologi informasi. Dampak yang didapat adalah teknologi informasi telah memberikan manfaat bagi karyawan dalam melakukan pendataan. Individu akan menggunakan teknologi untuk membantu menyelesaikan pekerjaannya (Suaryana, 2014). Adel (2013) menemukan bahwa kecanggihan teknologi berhungan positif dan signifikan terhadap karakteristik informasi akuntansi. Teknologi informasi sering digunakan untuk mengubah data mentah menjadi suatu informasi yang diperlukan oleh pihak internal dan eksternal. Informasi akuntansi dapat membantu manajemen untuk memperjelas tugasnya sebelum mengambil
keputusan(Suaryana, 2014).Sistem informasi akuntansi berguna untuk meningkatkan daya saing perusahaan agar tidak terlepas dari lingkungannya(Seviani, 2014). Partisipasi manajemen berperan penting sebagai pendukung pelaksanaanpengembangan sistem informasi akuntansi agarefektifitas sistem informasi akuntansi dapat meningkat.

Pengetahuan manajer akuntansi tentang sistem informasi juga menjadi faktor yang tidak kalah penting dalam penerapandan pengembangan sistem informasi akuntansi . Suaryana(2014)menyatakan bahwa manajer akuntansi (controller) merupakan pemegang kuasa tertinggi yang mengkoordinasikan partisipasi manajemen dalam perencanaan dan pengendalian untuk mencapai target perusahaan, 
terutama untuk pelaksanaan implementasi kebijakan dan mengembangkan struktur dan sistem organisasi. Manajer akuntansi merupakan pemegang kuasa tertinggi yang memiliki tanggung jawab atas keberlangsungan segala aktivitas didepartemen akuntansi. Tanggung jawab yang diembannyamengharuskan seorang manajer akuntansi memiliki pengetahuan yang tinggi tentangpenerapan sistem informasi akuntansi. Sistem informasi akuntansi akan menghasilkan laporan keuangan yang akan diserahkan kepada pihak manajemen dan akan digunakan sebagai alat pengambilan keputusan.

Sistem informasi akuntansi menjadi bagian yang sangat penting dalam meningkatkan efisiensi organisasi dan mendukung daya saing dengan menyediakan informasi keuangan dan akuntansi bagi manajemen (Alsarayreh,2011). Informasi yang berkualitas baik merupakan salah satu kelebuhan yang dimiliki oleh perusahaan (Suaryana,2014). Sistem dapat dikatakan efektif apabila sistem tersebut mampu menghasilkan informasi yang dapat diterima dan memenuhi harapan informasi secara tepat waktu (timely), akurat (accurate), dan dapat dipercaya (reliable) (Widjajanto,2001).

Sistem informasi akuntansi sangat berpengaruh pada organisasi. Efektivitas sistem informasi akuntansi sangat bergantung pada kinerja antara sistem, pemakai (user), dan sponsor. Faktor penting yang dapat mempengaruhi sistem informasi akuntansi diharapkan mempunyai pengaruh positif yang dapat menunjukkan tingkat kinerja sistem dalam menjalankan fungsinya(Suaryana, 2014).

Penelitian tentang sistem informasi akuntansi sebelumnya telah dilakukan oleh beberapa peneliti.pengguna dalam proses pengembangan sistem, ketrampilan teknis sistem informasi pribadi, organisasi, dukungan menejemen puncak, formalisasi pengembangan sistem informasi, pelatihan pengguna dan program pendidikan, keberadaan komite pengarah sistem informasi, dan lokasi departemen sistem informasi akuntansi adalah faktor-faktor yang memepengaruhi sistem informasi akuntansi (almilia, 2008).Ismail dan King (2007) menemukan bahwa kecanggihan teknologi informasi berpengaruh positif dan signifikan terhadap keselarasan atau kesesuaian teknologi informasi dengan strategi bisnis. Ekayani (2005) menyatakan bahwa fasilitas teknologi informasi mampu menciptakan hubungan yang baik dengan pihak eksternal perusahaan dan mempengaruhi daya saing perusahaan.

Keterlibatan manajemen juga mempengaruhi keberhasilan sistem. Pengembangan perilaku positif yang dipengaruhi oleh partisipasi manajer juga dapat meningkatkan efektifitas sistem informasi akuntansi.Manajemen perlu mengontrol dan mengetahui pentingnya sistem informasi akuntansi sebagai sumber daya strategis perusahaan (Widarno, 2008).

Dwitrayani (2012) mengungkapkan bahwa kecanggihan TI dan partisipasi manajemen berpengaruh signifikan terhadap efektivitas SIA. Begitu juga dengan penelitian Susilastri(2010) yang menunjukkan dukungan manajemen berpengaruh kuat terhadap sistem informasi akuntansi. Tingkat dukungan yang diberikan oleh manajemen puncak bagi sistem informasi organisasi dapat menjadi salah satu faktor yang sangat penting.

Kouser(2011) dalam penelitiannya menemukan bahwa pengetahuan manajer akuntansi dan partisipasi manajer dalam pelaksanaan dan pengembangan SIA memiliki hubungan yang kuat terhadap efektivitas sistem informasi akuntansi. Suaryana (2014) dalam penelitiannya ditemukan bahwa pengetahuan manajer akuntansi berpengaruh positif dan signifikan terhadap sistem informasi akuntansi.

Berbeda dengan penelitian terdahulu yang telah dilakukan oleh beberapa peneliti efektivitas SIA. Dalam penelitian ini peneliti memilih perusahaan yang bergerak dibidang jasa pengiriman barang dan dokumen di seluruh Indonesia dan luar negeri yang sudah menggunakan teknologi komputerisasi.

PT Indah Yatama Air Cargo dianggap mewakili populasi dimana perusahaan jasa ini memiliki fasilitas yang lengkap.PT Indah Yatama Air Cargo telah menerapakan Sistem Informasi Geografis (SIG) sebagai sistem informasi yang terintegritas guna mempermudah jalannya segala aktivitas. Sistem Informasi Geografis (SIG) merupakan sistem yang memproses seluruh proses pengolahan data bagian customer service, data entri dan accounting untuk mendukung kinerja dan dapat memperoleh informasi secara cepat, tepat dan akurat. 


\section{Landasan Teori}

Sistem adalah unsur yang bekerja secara berkelompok dan berhubungan erat satu sama lain sehingga dapat bekerja sama dalam menjalankan fungsi untuk mencapai tujuan (Mulyadi,2000:1). Secara umum, sebuah sistem terdiri dari input, pemrosesan, dan output. Hall (2001) menyatakan sistem sebagai sekumpulan komponen yang saling berkaitan satu sama lain dan yang digabungkan mencapai tujuan yang telah ditentukan sebelumnya.

Informasi didefinisikan sebagai suatu alat pengambil keputusan yang berupa oleh data (Bodnar dan William,2000:5).Jogiyanto (2000:25) menyebutkan bahwa informasi dikatakan sebagai data yang diolah menjadi sesuatu yang bermanfaat bagi para penerimanya atau dapat menjadi sesuatu yang bermanfaat dan dapat digunakan sebagai dasar pengambilan keputusan.

Jusup (2005:4) mendefinisikan akuntansi sebagai proses pencatatan, menghitung, pembuatan jurnal, pengikhtisaran, dan menganalisa data keuangan dari suatu organisasi. American Intitute of Certified Public Accounting (AICPA)menyatakan bahwa akuntansi adalah suatu proses pencatatan, mengklasifikasi, meringkas, mengolah dan menyajikan data suatu transaksi serta sesuatu yang berhubungan dengan keuangan sehingga mudah dimengerti sebagai salah satu alat pengambilan suatu keputusan.

$$
\text { Bodnar dan William (2000:1) }
$$

mendefinisikan sistem informasi akuntansi merupakan suatu komponen sumber daya, yang dapat digunakan untuk mengolah data menjadi informasi yang berguna. Jogiyanto (2000:49)menjelaskan bahwa sistem informasi akuntansi merupakan gabungan antar manusia dan sumber daya lain yang bertanggungjawab dalam menyediakan informasi dan informasi keuangan yang diperoleh melalui pengumpulan dan pengolahan data transaksi dalam suatu organisasi.

Hussin(2002) menjelaskan bahwa keragaman jumlah teknologi yang digunakan merupakan cerminan dari kecanggihan teknologi sedangkan portofolio merupakan gambaran dari kecanggihan informasi. Cragg (2010) mendefinisikan bahwa kecanggihan teknologi informasi sebagai suatu konstruksi yang mengacu pada penggunaan alam, kompleksitas dan saling ketergantungan teknologi informasi dan manajemen dalam suatu organisasi.Menurut Adel (2013)

Partisipasi manajemen dikonseptualisasikan sebagai keterlibatan dan partisipasi pelaksanaan atau manajemen di bidang Teknologi Informasi (TI)/Sistem Informasi (Igbaria,1996). Partisipasi manajemen adalah keterlibatan manajemen dalam melaksanakan sistem informasi dan strategi pengembangan untuk sistem informasi yang akan diimplementasikan. Partisipasi manajemen dalam memberikan dukunganmerupakan suatu panduan mengenai komitmen dan dukungan atas segala sumber daya yang diperlukan oleh perusahaan (Kouser, 2011).

Manajer Akuntansi juga sering disebut sebagai controller. Controller merupakan salah satu anggota manajemen puncak yang berpartisipasi dalam perencanaan, pengendalian dan pengambilan keputusan yang akan mempengaruhi perusahaan secara keseluruhan.

Efektivitas diartikan sebagai alat ukur untuk pencapaiankeberhasilan suatu tujuan yang ditetapkan. Siagian (2001:24) mendefisinikan efektivitas merupakan sumber daya, sarana, dan prasarana yang digunakan pada jumlah yang telah ditentukan untuk menghasilkan barang atas jasa kegiatan yang dilaksanakan. Efektivitas merupakan keberhasilan yangdiharapan dari hasil yang diperoleh dari pekerjaan yang telah dilakukan (Kristiani,2012). Ompusunggu (2002) memberikan definisi efektivitas sebagai suatu keberhasilan kualitas, kuantitas, waktu yang digunakan dan hasil kerja yang telah dicapai. Mc Lean (2003) mengemukakan enam dimensi pengukuran efektifitas istem informasi akuntansi

Kualitas Informasi (Information Quality) merupakan output dari penggunan sistem informasi oleh pengguna (user). Variabel ini menggambarkan kualitas informasi yang dipersepsikan oleh pengguna yang diukur dengan keakuratan informasi (accuracy), relevan (relevance), kelengkapan informasi (completeness), ketepatan waktu (timeliness), danpenyajian informasi (format). Indikator pengukuran kualitas sistem dari DeLone dan McLean: Kelengkapan, relevan, akurat, ketepatan waktu, penyajian informasi.

$$
\text { Kualitas layanan merupakan }
$$

keseluruhan dukungan yang ditawarkan bagian 
TI dan penyedia layanan kepada para penggunan, memastikan sistem dapat diaplikasikan dengan baik secara internal maupun eksternal (McLean: 2003). Menurut Petter (2008), terdapat empat komponen utama terkait dengan kualitas layanan yaitu: kecepatan tanggap, jaminan, kepercayaan/reliability, empati.

\section{METODE PENELITIAN}

Populasi dalam penelitian ini adalah pengguna sistem informasi akuntansi pada PT Indah Yatama Air Cargo di Jateng dibagian manajer, administrasi keuangan, customer service, dan data entry dengan total sebanyak 36 orangSampel dalam penelitian ini adalah seluruh anggota populasi dijadikan sampel yaitu pemakai sistem informasi akuntansi pada PT IndahYatama Air Cargo di Jateng.

Tabel 1. Uji Validitas Kecanggihan Teknologi Informasi

\begin{tabular}{ccccc}
\hline $\begin{array}{c}\text { Item } \\
\text { Pernyataan }\end{array}$ & rhitung & rtabel & Sig & Keterangan \\
\hline X1.1 & 0,643 & 0,329 & 0,000 & Valid \\
X1.2 & 0,757 & 0,329 & 0,000 & Valid \\
X1.3 & 0,604 & 0,329 & 0,000 & Valid \\
X1.4 & 0,626 & 0,329 & 0,000 & Valid \\
X1.5 & 0,638 & 0,329 & 0,000 & Valid \\
X1.6 & 0,711 & 0,329 & 0,000 & Valid \\
X1.7 & 0,794 & 0,329 & 0,000 & Valid \\
X1.8 & 0,773 & 0,329 & 0,000 & Valid \\
X1.9 & 0,836 & 0,329 & 0,000 & Valid \\
X1.10 & 0,702 & 0,329 & 0,000 & Valid \\
\hline
\end{tabular}

Sumber: data primer yang diolah 2021

Tabel 2.Uji Validitas Partisipasi Manajemen

\begin{tabular}{ccccc}
\hline $\begin{array}{c}\text { Item } \\
\text { Pernyataan }\end{array}$ & $\mathbf{r}_{\text {hitung }}$ & $\mathbf{r}_{\text {tabel }}$ & Sig & Keterangan \\
\hline X2.1 & 0,641 & 0,329 & 0,000 & Valid \\
X2.2 & 0,780 & 0,329 & 0,000 & Valid \\
X2.3 & 0,685 & 0,329 & 0,000 & Valid \\
X2.4 & 0,822 & 0,329 & 0,000 & Valid \\
X2.5 & 0,772 & 0,329 & 0,000 & Valid \\
X2.6 & 0,745 & 0,329 & 0,000 & Valid \\
X2.7 & 0,709 & 0,329 & 0,000 & Valid \\
X2.8 & 0,830 & 0,329 & 0,000 & Valid \\
X2.9 & 0,809 & 0,329 & 0,000 & Valid \\
X2.10 & 0,734 & 0,329 & 0,000 & Valid \\
\hline
\end{tabular}

Sumber: data primer yang diolah 2021

Tabel 3.Uji Validitas Penegetahuan Manajer Akuntansi

\begin{tabular}{ccccc}
\hline $\begin{array}{c}\text { Item } \\
\text { Pertanyaan }\end{array}$ & $\mathbf{r}_{\text {hitung }}$ & $\mathbf{r}_{\text {tabel }}$ & Sig & Keterangan \\
\hline X3.1 & 0,881 & 0,329 & 0,000 & Valid \\
X3.2 & 0,921 & 0,329 & 0,000 & Valid \\
X3.3 & 0,864 & 0,329 & 0,000 & Valid \\
X3.4 & 0,850 & 0,329 & 0,000 & Valid \\
X3.5 & 0,854 & 0,329 & 0,000 & Valid \\
\hline
\end{tabular}

Sumber: data primer yang diolah 2021 
Jurnal Akuntansi dan Pajak, 22(01), 2021, 12

Tabel 4.Uji Validitas Efektivitas Sistem Informasi Akuntansi

\begin{tabular}{ccccc}
\hline $\begin{array}{c}\text { Item } \\
\text { Pernyataan }\end{array}$ & $\mathbf{r}_{\text {hitung }}$ & $\mathbf{r}_{\text {tabel }}$ & Sig & Keterangan \\
\hline Y.1 & 0,608 & 0,329 & 0,000 & Valid \\
Y.2 & 0,716 & 0,329 & 0,000 & Valid \\
Y.3 & 0,545 & 0,329 & 0,000 & Valid \\
Y.4 & 0,641 & 0,329 & 0,000 & Valid \\
Y.5 & 0,568 & 0,329 & 0,000 & Valid \\
Y.6 & 0,791 & 0,329 & 0,000 & Valid \\
Y.7 & 0,588 & 0,329 & 0,000 & Valid \\
Y.8 & 0,506 & 0,329 & 0,000 & Valid \\
Y.9 & 0,526 & 0,329 & 0,000 & Valid \\
Y.10 & 0,685 & 0,329 & 0,000 & Valid \\
Y.11 & 0,652 & 0,329 & 0,000 & Valid \\
Y.12 & 0,802 & 0,329 & 0,000 & Valid \\
Y.13 & 0,711 & 0,329 & 0,000 & Valid \\
Y.14 & 0,669 & 0,329 & 0,000 & Valid
\end{tabular}

\section{Uji Reliabilitas}

Untuk mengukur reliabilitas dengan uji statistik Cronbach's Alpha $(\alpha)$ dikatakan reliabel jika meberikan nilai Cronbach Alpha> 0,60 sampai dengan 0,90.

Tabel 5. Uji Reliabilitas Variabel Penelitian

\begin{tabular}{|c|c|c|c|}
\hline Variabel & $\begin{array}{c}\text { Cronbach's } \\
\text { Alpha }\end{array}$ & Kriteria & Keterangan \\
\hline $\begin{array}{l}\text { Kecanggihan Teknologi } \\
\text { Informasi }\end{array}$ & 0,888 & 0,80 & Reliabel \\
\hline Partisipasi Manajemen & 0,913 & 0,80 & Reliabel \\
\hline $\begin{array}{c}\text { Pengetahuan Manajer } \\
\text { Akuntansi }\end{array}$ & 0,922 & 0,80 & Reliabel \\
\hline $\begin{array}{l}\text { Efektivitas Sistem } \\
\text { Informasi Akuntansi }\end{array}$ & 0,888 & 0,80 & Reliabel \\
\hline
\end{tabular}

Sumber: data primer yang diolah 2021

\section{Uji Normalitas}

Uji normalitas bertujuan untuk menguji apakah dalam model regresi, variabel pengganggu atau residual memiliki distribusi normal.Uji normalitas yang digunakan dalam penelitian ini adalah metode uji Kolmogorov-Smirnov $(K-S)$.Model regresi yang baik adalah yang memiliki distribusi secara normal. Apabila nilai signifikan $>0,50$, maka lolos uji normalitas.

Tabel 6. Uji Normalitas

\begin{tabular}{ccc}
\hline One-sample & Sig & Keterangan \\
Kolmogorov-Smirnov & &
\end{tabular}

$\begin{array}{ccc}\text { Unstandardized } & 0,169 & \text { Normal } \\ \text { Residual } & & \end{array}$

Sumber: data primer yang diolah 2021

Dari tabel 6 dapat diperoleh nilai Sig sebesar 0,169>0,05, sehingga data dinyatakan berdistribusi normal dan lolos uji normalitas data. 


\section{Uji Multikolinearitas}

Deteksi multikoliniearitas pada suatu model dapat dilihat jika nilai Variance Inflantion Factor (VIF)tidak lebih dari 10 dan nilai tolerance kurang dari 0,1 , maka model tersebut dapat dikatan bebas dari multikolinearitas.

Tabel 7. Uji Multikolinearitas

\begin{tabular}{|c|c|c|c|}
\hline \multirow{2}{*}{ Variabel } & \multicolumn{2}{|c|}{ Collinearity Statistics } & \multirow{2}{*}{ Keterangan } \\
\hline & Tolerance & VIF & \\
\hline $\begin{array}{l}\text { Kecanggihan } \\
\text { Teknologi } \\
\text { Informasi }\end{array}$ & 0,361 & 2,773 & $\begin{array}{l}\text { Tidak terjadi } \\
\text { multikolinearitas }\end{array}$ \\
\hline $\begin{array}{l}\text { Partisipasi } \\
\text { Manajemen }\end{array}$ & 0,301 & 3,323 & $\begin{array}{c}\text { Tidak terjadi } \\
\text { multikolinearitas }\end{array}$ \\
\hline $\begin{array}{c}\text { Pengetahuan } \\
\text { Manajer } \\
\text { Akuntansi }\end{array}$ & 0,448 & 2,233 & $\begin{array}{c}\text { Tidak terjadi } \\
\text { multikolinearitas }\end{array}$ \\
\hline
\end{tabular}

Sumber: data primer yang diolah 2021

Dari tabel 7 diperoleh nilai toleransi $>0,1$ dan nilai VIF $<10$, sehingga data dinyatakan tidak terdapat masalah multikolinearitas antar variabel Kecanggihan Teknologi Informasi, Partisipasi Manajemen, dan Pengetahuan Manajer Akuntansi dalam model regresi.

\section{Pengujian Hipotesis}

\section{Analisa Regresi Linier Berganda}

Analisa regresi linier berganda digunakan untuk menegetahuipengaruh kecanggihan teknologi informasi, partisipasi manajemen, dan pengetahuan manajer akauntansi dengan efektivitas sistem informasi akauntansi.

Tabel 8.Uji Regresi Linier Berganda

\begin{tabular}{lcc}
\hline \multicolumn{1}{c}{ Variabel } & Koefisien Regresi & Standar Error \\
\hline constant & 16,027 & 6,717 \\
Kecanggihan Teknologi & 0,564 & 0,255 \\
Informasi & & \\
Partisispasi Manajemen & 0,430 & 0,249 \\
Pengetahuan Manajer & 0,057 & 0,376 \\
Akuntansi & & \\
\hline
\end{tabular}

Sumber: data primer yang diolah 2021

Persamaan koefisien regresi linear berganda sebagai berikut:

$$
\mathrm{Y}=16,027+0,564 \mathrm{X}_{1}+0,430 \mathrm{X}_{2}+0,057 \mathrm{X}_{3}
$$

Persamaa tersebut dapat diinterprestasikan sebagai berikut:

16,027 artinya bahwa apabila tidak ada variabel independen Kecanggihan Teknologi Informasi Partisipasi Manajemen danPengetahuan Manajer Akuntansimaka Efektivitas Sistem Infoemasi Akuntansi mempunyai rata-rata sebesar 16,027.0,564 menunjukkan bahwa Kecanggihan Teknologi Informasi mempunyai hubungan yang searah dengan Efektivitas
Sistem Informasi Akuntansi, artinya bahwa setiap kenaikan Kecanggihan Teknologi Informasi satu satuan maka variabel Efektivitas Sistem Informasi Akuntansi akan bertambah sebesar 0,564 dengan asumsi bahwa variabel bebas yang lain dari model regresi adalah tetap. 0,430 Partisipasi Manajemen mempunyai hubungan yang searah dengan Efektivitas Sistem Informasi Akuntansi bahwa setiap kenaikan Partisipasi Manajemen satu satuan 
maka variabel Efektivitas Sistem Informasi Akuntansi akan bertambah sebesar 0,430 dengan asumsi bahwa variabel bebas yang lain dari model regresi adalah tetap.Nilai koefisisen regresi 0,057 menunjukkan bahwa Pengetahuan Manajer Akuntansi mempunyai hubungan yang searah dengan Efektivitas Sistem Informasi Akuntansi bahwa setiap kenaikan Pengetahuan Manajer Akuntansi satu satuan maka variabel Efektivitas Sistem Informasi Akuntansi akan bertambah sebesar 0,057 dengan asumsi bahwa variabel bebas yang lain dari model regresi adalah tetap.Berdasarkan hasil analisis diketahui bahwa Kecanggihan Teknologi Informasi mempunyai pengaruh paling dominan terhadap efektivitas sistem informasi akuntansi, karena mempunyai nilai koefisien regresi paling tinggi yaitu sebesar 0,564 .

\section{Uji F}

Uji F digunakan untuk mengetahui secara bersama-sama pengaruh yang signifikan anatara Kecanggihan Teknologi Informasi, Partisipasi Manajemen, Pengetahuan Manajer Akuntansi terhadap Efektivitas Sistem Informasi Akuntansi.

Tabel 9.Hasil Uji F

\begin{tabular}{crcccc}
\hline Model & $\begin{array}{c}\text { Sum of } \\
\text { Squares }\end{array}$ & df & $\begin{array}{c}\text { Mean } \\
\text { Square }\end{array}$ & F & Sig \\
\hline Regression & 750,073 & 3 & 250,024 & 14,682 & 0,000 \\
Residual & 544,927 & 32 & 17,029 & & \\
Total & 1295,000 & 35 & & & \\
\hline
\end{tabular}

Sumber: data primer yang diolah 2021

Menentukan hipoteis

Ho : $\beta_{1}=\beta_{2}=\beta_{3}=0$ artinya tidak ada pengaruh yang signifikan secara bersama-sama antara variabel Kecanggihan Teknologi Informasi, Partisipasi Manajemen, dan Pengetahuan Manajer Akuntansiterhadap variabel Efektivitas Sistem Informasi Akuntansi.

Ha : $\beta_{1}=\beta_{2}=\beta_{3} \neq 0$ artinya ada pengaruh yang signifikan secara bersama-sama antara variabel Kecanggihan Teknologi Informasi, Partisipasi Manajemen, dan Pengetahuan Manajer
Akuntansiterhadap variabel Efektivitas Sistem Informasi Akuntansi.

Hasil penelitian diperoleh nilai $\mathrm{F}_{\text {hitung }}>\mathrm{F}_{\text {tabel }}$ $(14,628>2,90)$ dan diperoleh nilai Sig $<0,05$ $(0,000<0,05)$, maka Ho ditolak dan $\mathrm{Ha}$ diterima artinya secara bersama-sama (simultan) Kecanggihan Teknologi Informasi, Partisipasi Manajemen, Pengetahuan Manajer Akuntansi berpengaruh signifikan terhadap Efektivitas Sistem Informasi Akuntansi.

\section{Uji t}

Tabel 10.Hasil Uji t

\begin{tabular}{lcc}
\hline \multicolumn{1}{c}{ Variabel } & T & Sig. \\
\hline Kecanggihan Teknologi Informasi & 2,211 & 0,034 \\
Partisipasi Manajemen & 1,730 & 0,093 \\
Pengetahauan Manajer Akuntansi & 0,152 & 0,880 \\
\hline
\end{tabular}

Sumber: data primer yang diolah 2021

Pengaruh Kecanggihan Teknologi Informasi Terhadap Efektivitas Sistem Informasi Akuntansi denganhasil uji $\mathrm{t}$ diperoleh nilai $t_{\text {hitung }}$ sebesar 2,211 dan $t_{\text {tabel }}$ sebesar 2,037. Maka $t_{\text {hitung }}>t_{\text {tabel }}$ yaitu 2,211 > 2,037 dan nilai signifikan 0,034 < 0,05 maka dapat disimpilkan Ho ditolak dan $\mathrm{H}_{\mathrm{a}}$ diterima, artinya secara parsial kecanggihan teknologi informasi berpengaruh signifikan terhadap efektivitas sistem informasi akuntansi.

Pengaruh Partisipasi Manajemen terhadap efektivitas Sistem Informasi Akuntansi dengan hasil uji t diperoleh nilai 
$t_{\text {hitung }}$ sebesar 1,730 dan $t_{\text {tabel }}$ sebesar 2,037. Maka $t_{\text {hitung }}<t_{\text {tabel }}$ yaitu $1,730<2,037$ dan nilai signifikan $0,093>0,05$ maka dapat disimpulkan Ho diterima dan $\mathrm{H}_{\mathrm{a}}$ ditolak, artinya secara parsial Partisipasi Manajemen tidak berpengaruh signifikan terhadap Efektivitas Sistem Informasi Akuntansi.

Pengaruh Pengetahuan Manajer Akuntansi terhadap Sistem Informasi
Akuntansi denan hasil uji t diperoleh nilai $t_{\text {hitung }}$ sebesar 0,152 dan $t_{\text {tabel }}$ sebesar 2,037. Maka $t_{\text {hitung }}<\mathrm{t}_{\text {tabel }}$ yaitu $0,152<2,037$ dan nilai signifikan $0,880>0,05$ maka dapat disimpilkan Ho diterima dan $\mathrm{H}_{\mathrm{a}}$ ditolak, artinya secara parsial Pengetahuan Manajer Akuntansi tidak berpengaruh signifikan terhadap Efektivitas Sistem Informasi Akuntansi.

\section{Tabel 11.Hasil Uji Koefisien Determinasi}

\begin{tabular}{cccc}
\hline $\mathbf{R}$ & $\begin{array}{c}\boldsymbol{R} \\
\text { Square }\end{array}$ & $\begin{array}{c}\text { Ajusted } \boldsymbol{R} \\
\text { Square }\end{array}$ & $\begin{array}{c}\text { Std. Error of the } \\
\text { Estimate }\end{array}$ \\
\hline 0,761 & 0,579 & 0,540 & 4,127
\end{tabular}

Menunjukkan bahwa nilai Ajusted $R$ Square $\left(\mathrm{R}^{2}\right)$ adalah 0,540 atau $54,0 \%$. Hal ini berarti bahwa pengaruh variabel Kecanggihan Teknologi Informasi, Partisipasi Manajemen dan Pengetahuan Manajer Akuntansi secara bersama-sama memberikan kontribusi positif terhadap Efektivitas Sistem Informasi Akuntansi sebesar $54,0 \%$, sedangkan sisanya $46,0 \%$ dipengaruhi oleh variabel lain diluar penelitian.

\section{PEMBAHASAN HASIL PENELITIAN}

Secara bersama-sama Kecanggihan Teknologi Informasi, Partisipasi Manajemen, Pengetahuan Manajer Akuntansi berpengaruh signifikan terhadap Efektivitas Sistem Informasi Akuntansi pada PT Indah Yatama Air Cargo Jateng. Efektifitas sistem informasi akuntansi adalah suatu ukuran yang memberikan gambaran sejauh mana target dapat dicapai dari suatu kumpulan sumber daya yang diatur untuk mengumpulkan, memproses dan menyimpan data eloktronik, kemudian mengubahnya menjadi sebuah informasi yang berguna serta menyediakan laporan formal yang dibutuhkan dengan baik secara kualitas maupun waktu.

Hasil penelitian ini sejalan dengan penelitian yang dilakukan oleh Ratnaningsi (2014), Pradani (2017), Seviani (2017), dan Dwitrayani (2017) yamg mana hasil penelitian diperoleh menyatakan bahwa Teknologi Informasi, Partisipasi
Manajemen, dan Pengetahuan Manajer Akuntansi berpengaruh secara simultan terhadap Efektivitas Sistem Informasi Akuntansi.

Kecanggihan Teknologi Informasi berpengaruh signifikan terhadap Efektivitas Sistem Informasi Akuntansi pada PT Indah Yatama Air Cargo.

Kecanggihan teknologi merupakan sumber kekuatan yang menjadikan perusahaan memiliki keunggulan kompetitif, serta diidentifikasikan sebagia faktor yang memberikan retribusi terhadap keberhasilan perusahaan.Oleh karena itu kecanggihan teknologi memiliki pengaruh yang tinggi terhadap keberhasilan perusahaan dalam mengelola perusahaan.Sehingga semakin canggih teknologi informasi yang diterapkan maka efektivitas sistem informasi yang yang di hasilkan semakin baik pula.

Penelitian ini sejalan dengan penelitian yang dilakukan oleh Ratnaningsih (2014), Pradani (2017), Seviani (2017), dan Dwitrayani (2017) yang menyimpulkan bahwa pemanfaatan kecanggihan teknologi informasi berpengaruh secara signifikan terhadap efektivitas sistem informasi akuntansi.

Partisipasi Manajemen tidak berpengaruh signifikan terhadap Efektivitas Sistem Informasi Akuntansi pada PT Indah Yatama Air Cargo

Partisipasi manajemen mengandung makna adanya keterlibatan para karyawan dalam aspek mental dan emosional yang 
mendorong mereka berkontribusi dalam pencapaian tujuan perusahaan.

Bentuk partisipasi ini seharusnya merupakan proses komunikasi atau teknik mendapatkan dan memanfaatkan umpan balik karyawan dalam pengambilan keputusan. Namun, dalam hal ini pihak karyawan tidak memiliki otoritas dalam pengambilan keputusan.

Secara teoritis , partisipasi manajemen diharapkan dapat membantu meningkatkan kinerja dan perilaku yang baik bagi karyawan. Partisipasi manajemen adalah keterlibatan manajemen dalam melaksanakan sistem informasi dan strategi pengembangan untuk sistem informasi yang akan diimplementasikan.. Partisipasi manajemen dalam memberikan dukungan merupakan suatu panduan mengenai komitmen dan dukungan atas segala sumber daya yang diperlukan oleh perusahaan (Ann Mooney: 2008)

Hasil penelitian ini sejalan dengan penelitian seviani (2017) dan Leonardo (2019) yang menunjukkan hasil Patisipasi Manajemen tidak berpengaruh signifikan terhadap Evektivitas Sistem Informasi Akuntansi. Sedangkan hasil penelitian ini bertolak belakang dengan penelitian yang dilakukan oleh Ratnaningsih (2014), Pradani (2017), Yuniasih (2017) dan Dwitrayani (2017) bahwa keterlibatan partisipasi manajemen dalam implementasi dan pengembangan sistem informasi akuntansi menjadi satu faktor penting dalam keberhasilan sistem informasi akuntansi untuk menghasilkan kualitas informasi yang tepat, akurat, dan dapat dipercaya.

Pengetahuan Manajer Akuntansi tidak berpengaruh signifikan terhadap Efektivitas Sistem Informasi Akuntansi pada PT Indah Yatama Air Cargo. Hal ini menunjukkan bahwa pengetahuan manajer akuntansi tidak menjadi faktor utama penentu keberhasilan efektifitas sitem informasi akuntansi pada PT Indah Yatama Air Cargo di Surakarta dan Semarang karena manajemen puncak tidak berperan aktif secara langsung dalam perencanaan, pengendalian dan pengambilan keputusan.

Secara teoritis, pengetahuan yang dimiliki oleh para manajer disuatu organisasi mempengaruhi cara mereka dalam melakukan pengambilan keputusan, baik keputusan taktis maupun strategis. Pengetahuan yang dimiliki para manajer disuatu organisasi juga mempengaruhi mereka dalam memilih dan menggunakan informasi, metode, cara-cara dan strategi yang dibutuhkan organisasi untuk mencapai tujuan.

Hasil Penelitian ini sejalan dengan penelitian Leonardo (2019) yang menunjukkan hasil Pengetahuan Manajer Akuntansi tidak perbengaruh signifikan terhadap Sistem Informasi Akuntansi. Sedangkan hasil Penelitian ini bertolak belakang dengan penelitian Ratnaningsih (2017), Pradani (2017), dan Seviani (2017) dimana hasil penelitiannya menunjukkan bahwa pengetahuan manajer akuntansi berpengaruh signifikan terhadap efektifitas sistem informasi akuntansi.

\section{KESIMPULAN}

Kecanggihan Teknologi Informasi, Partisipasi Manajemen, Pengetahuan Manajer akuntansi secara simultan berpengaruh signifikan terhadap Efektivitas Sistem Informasi Akuntansi pada PT. Indah Yatama Air Cargo. Hal ini dibuktikan dari hasil penelitian diperoleh nilai $F_{\text {hitung }}>F_{\text {tabel }}(14,628>2,90)$ dan diperoleh nilai $\mathrm{Sig}<0,05(0,000<0,05)$ artinya secara bersama-sama Kecanggihan Teknologi Informasi, Partisipasi Manajemen, Pengetahuan Manajer Akuntansi berpengaruh signifikan terhadap Efektivitas Sistem Informasi Akuntansi pada PT Indah Yatama Air Cargo.

Kecanggihan Teknologi Informasi berpengaruh signifikan terhadap Efektivitas Sistem Informasi Akuntansi pada PT. Indah Yatama Air Cargo Hal ini dibuktikan dari hasil analisa regresi uji $t$ diperoleh nilai $t_{\text {hitung }}$ sebesar 2,211 dan $t_{\text {tabel }}$ sebesar 2,037. Maka $t_{\text {hitung }}>t_{\text {tabel }}$ yaitu 2,211 > 2,037 dan nilai signifikan 0,034< 0,05 , artinya secara parsial Kecanggihan Teknologi Informasi berpengaruh signifikan terhadap Efektivitas Sistem Informasi Akuntansi pada PT Indah Yatama Air Cargo.

Partisipasi Manajemen secara parsial tidak berpengaruh signifikan terhadap Efektivitas Sistem Informasi Akuntansi pada PT. Indah Yatama Air Cargo di Surakarta dan Semarang. Hal ini dibuktikan dari hasil analisa regresi uji t 
diperoleh nilai $t_{\text {hitung }}$ sebesar 1,730 dan $t_{\text {tabel }}$ sebesar 2,037. Maka $t_{\text {hitung }}<t_{\text {tabel }}$ yaitu $1,730<$ 2,037 dan nilai signifikan 0,093>0,05 maka artinya Partisipasi Manajemen tidak berpengaruh signifikan terhadap Efektivitas Sistem Informasi Akuntansi pada PT Indah Yatama Air Cargo.

Pengetahuan Manajer Akuntansi tidak berpengaruh signifikan terhadap Efektivitas Sistem Informasi Akuntansi (Y) pada PT. Indah Yatama Air Cargo di Surakarta dan Semarang.Hal ini dibuktikan dari hasil analisa regresi uji $t$ diperoleh nilai $t_{\text {hitung }}$ sebesar 0,152 dan $t_{\text {tabel }}$ sebesar 2,037. Maka $t_{\text {hitung }}<t_{\text {tabel }}$ yaitu $0,152<2,037$ dan nilai signifikan 0,880 >0,05, artinya Pengetahuan Manajer Akuntansi tidak berpengaruh signifikan terhadap Efektivitas Sistem Informasi Akuntansi pada PT Indah Yatama Air Cargo.

\section{Referensi}

Al E, Mahmod, Dalia A. (2013). The Impact of IT Sophistications on The Perceived Usefulness Of Accaunting Information Characteristics among Jordanian Listed Companies. International Journal of Business and Social Sciense. 4(3), pp: 143-155.

Almilia, L.S, Briliantin.( 2008). Faktor-faktor yang Mempengaruhi Kinerja Sistem Informasi Akuntansi pada Bank Umum Pemerintah di Wilayah Surabaya dan Sidoarjo. Surabaya. STIE Perbanas Surabaya.

Alsarayreh. M.N., Jawabreh O.A., Jadarat M.F., Alamro S.A. 2011. Technological Impact on Effectiveness of Accounting Information System (AIS) Applied by Aqaba Tourist Hotels. European Journal of Scientific Research, 59(3), pp: 361-369

Ann M, Micheal M., Barbara W. (2008). Achieng Top Management Support in Strategi Technology Initiatives. Howe School Alliance For Technology Manajement, 12(2), pp:1-3.

Anwar, A. (2012). Pengaruh Komitmen Organisasional dan Pengetahuan Manajer terhadap Keberhasilan Sistem
Informasi Akuntansi dan

Dampaknya terhadap Kinerja Keuangan Perusahaan (Survey pada BUMN di Indonesia). Jurnal SNA. Universitas Pekalongan. Pekalongan.

Arikunto, S. (2002). Metodologi Peneleitian Suatu Pendekatan Proposal. Jakarta: PT. Rineka Cipta.

Bodnar, Gorger. H.,William.H. (2000). Sistem Informasi Akuntansi.Jakarta : Salemba Empat.

Candra. P., Ni L., Edy S., I Gusti A. P. (2017). Pengaruh Kecanggihan Teknologi Informasi, Perlindungan Sitsem Informasi, Partisipasi Manajemen, dan Penegtahuan Manajer Akuntansi terhadap Efektivitas Sistem Informasi Aakuntansi pada Hotel Berbintang di Kabupaten Karangasem. Journal Akuntansi Universitas Pendidikan Ganesha.7(1).

Cragg, P., Mills. A., Suraweera,T. (2010). Understanding IT Management in SMEs.Elektronic Journal Information Systems Evaluation, 13(1), pp: 27-34.

Dwitrayani, Made C., Widanaputra., A.A.G.P., Made A. D. P. (2017). Pengaruh Kecanggihan Teknologi Informasi, Partispasi Manajemen, Budaya Organisasi, dan Kepuasan Pengguna pada Efektivitas Sistem Informasi Akuntansi Bank Pengkreditan Rakyat di Kabupaten Bandung. E-Journal Ekonomi dan Bisnis Universitas Udayana. 6(1), h: 197-222.

Efendi, T. (2016). Pengaruh Pengetahuan Karyawan Bagian Akuntansi, Partisipasi Manajemen, dan Pemanfaatan Teknologi Informasi terhadap Efektivitas Sistem Informasi Akuntansi. Jurnal Akuntansi.Universitas Muhammadiyah Surakarta.

Ekayani, Ni Nengah Sri., Ghozali, Imam.,dan Zulaekha. 2005. Analisis Kontribusi Nilai Teknologi Informasi Terhadap Efektivitas Proses Bisnis DanDinamika Bersaing.Jurnal SNA VIII. (pp.820-83) 
Ghozali, I. (2011). Aplikasi Aanalisis Multivariate Dengan Program SPSS. Semarang: Badan penerbit Universitas Diponegoro.

Hall, J. A. (2001). Sistem Informasi Akuntansi. Jakarta: Salemba Empat

Hussin, H., King. M.,Cragg, P.B. (2002). Alignment in Small Firms. European Journal of Information Systems, 11 (1), pp: 108-127

Igbaria, M., Baroudi, J.,Parasurama, S. (1996). A Mutivational Model of Microcomputer Usage. Jurnal of Management Information Systems, 13 (1), pp: 127-143

Ismail, N.A., King . M. 2007. Factor Influencing the Aligment of Accounting Information System in Small and Medium Sized Malaysian Manufacturing Firms. Jurnal of Information System and Small Business, 1(1-2), pp: 1-19.

Jogiyanto. (2000). Sistem Informasi Berbasis Komputer. Edisi Kedua. Yogyakarta: BPFE

Jusup.,H. (2005). Dasar-dasar Akuntansi. Yogyakarta: STIE YKPN

Kristiani, Wahyu. 2012. Analisa Pengaruh Efektifitas Teknologi Sistem Informasi Akuntansi Terhadap Kinerja Individual.Jurnal Akuntansi Fakultas Ekonomi Universitas Gunadarma.

Kouser, R,G.R.,Farasad. A. S. (2011). Determinants of AIS Effectiveness: Assessment Thereof in Pakistan. International Journal of Contenporary Bussiness Studies, 2 (12), pp:6-21

Meliyawati., M. (2016). Pengaruh Kecanggihan Teknologi Informasi, Partisispasi Manjemen, dan Pengetahuan Manajer Akuntansi terhadap Efektivitas Sitem Informasi Akuntansi ( studi pada PT PLN (persero) distribusi Jawa Barat dan Banten).
Mulyadi. (2001). Sistem Informasi Akuntansi. Jakarta: Salemba Empat.

Ompusunggu, Halomuan. 2002. Pengaruh Penerapan Sistem Informasi Akuntansi terhadap Efektifitas Pelaksanaan Sistem Pengendalian Internal.Jurnal Akuntansi (2), h:1-9.

Ratnaningsih, Kadek I., I Gusti N. A. S. (2014). Pengaruh Kecanggihan Teknologi, Partisipasi Manajemen, dan Pengetahuan Manajer Akuntansi pada Efektivitas Sistem Informasi Akuntansi. E- Journal Akuntansi Universitas Udayana 6(1), pp:1-16.

Seviani, E. (2017). Pengaruh Kecanggihan Teknologi Informasi, Partisipasi Manajemen, dan Pengetahuan Manajer Akuntansi pada Efektivitas Sistem Informasi Akuntansi. Skripsi.Universitas Muhammadiyah Yogyakarta.

Siagian, Sondang P. (2001). Manajemen Sumber Daya Manusia. Jakarta: Bumi Aksar

Sonia, S. (2018). Pengaruh Kecaggihan Teknologi Informasi, Partisispasi Manajemen, dan Kemampuan Teknik Pemakai Sistem Informasi Akuntansi Terhadap Kinerja Individu pada Karywan Koperasi Repubil Indonesia (KPRI) di Kabupaten Bondowoso. Skripsi. Unibersitas Jember.

Susilastri., Tanjung., A R., Pebrina, S. (2010). Faktor-Faktor Yang Mempengaruhi Kinerja Sistem Informasi Akuntansi Pada Bank Umum Pemerintah Di Kota Pekanbaru. Jurnal Ekonomi, 18 (2),(pp. 121-132)

Sugiyono.( 2014). Metode Penelitian Bisnis. Bandung: Alfabeta.

Widarno, Bambang. 2008. Efektivitas Perencanaan dan Pengembangan Sistem Informasi.Jurnal Akuntansi dan Sistem Teknologi Informasi, 6 (1), h: 1-13. 
Widjajanto, N. (2001). Sistem Informasi Akuntansi. Jakarta: Erlangga

Yuniasih, N.W. (2017). Pengaruh Information Technology Sophistication, Partisipasi Manajemen, Pengetahuan Manajemen dan External Expertise pada Efektivitas Sistem Informasi AkuntansiJurnal Riset Akuntansi

Universitas

Hindu

Indonesia.7(2) 